\title{
Protected and partially protected fat sources from ruminal degradation for pregnant sheep
}

Received: Jun 2020; Accepted: Aug 2020

\section{Luciana Melo Sousa ${ }^{1^{*}}$, Maria Julia Pereira de Araújo ${ }^{2}$, Adriana Lima Silva², Thauane Ariel Valadares de Jesus ${ }^{2}$, Karla Alves Oliveira ${ }^{1}$, Gilberto de Lima Macedo Júnior ${ }^{2}$}

\begin{abstract}
Fat sources are important component on animal feed. However, ruminants did not evolve to efficient degrade lipids. Thus, it is necessary to study how its supplementation may affect animal performance. The objective of this study was to evaluate the use of different lipids sources over consumption, performance, metabolites, and feed behavior of pregnant sheep. The experiment was carried out at Capim Branco Experimental Farm, at goat and sheep sector of Federal University of Uberlândia, from August to November 2015. Twenty-four pregnant sheep were used, mean body weight $50 \mathrm{~kg}$ and approximate 12 months age. The animals were divided into three treatments (Control, palm oil protected fat and cottonseed). The corn silage was used as the bulk. The roughage: concentrate ratio was 60:40 (on dry matter). Measurements of body weight, body condition score and biometric measurements were taken every 21 days. Ingestive behavior evaluation was performed throughout the experiment. The consumption measurement was made in descriptive way. Shortly after birth, the sheep and their offspring were weighed, the barrel circumference was taken, and samples from the mother's blood were collected. The experimental design was completely randomized with repeated measurements in time. It was verified greater time spent with feeding and chewing in the treatment with cottonseed and consequently less time in idle. There was no statistical difference in weight, barrel circumference (BC) and body condition score (BCS) of the sheep under the different treatments. There was a linear growth in $\mathrm{BC}$ measurements and sheep weight over the evaluated periods. There were differences between the treatments for the offspring's average weight. The use of cottonseed as a fat source increases the birth weight of the progeny and improves pregnant sheep metabolic profile in relation to inert fat.
\end{abstract}

Keywords: Cottonseed, Inert fat, Nutrition, Ovis aries.

\footnotetext{
${ }^{1}$ Paulista State University “Júlio de Mesquita Filho”, Jaboticabal, São Paulo

${ }^{2}$ School of Veterinary Medicine, Federal University of Uberlândia, Uberlândia, Minas Gerais

* Corresponding author: lumelosousa@gmail.com, Rua Adolfo Carlos Carísio, n 770, Bairro Industrial, Araguari-MG, CEP: 38442-038. Tel.: (034) 98806-7476
} 


\section{Introduction}

Ewes in the pregnancy final third show a decrease in feed consumption due to physical limitations of the rumen. It occurs due to the fetus growth as well as it leads to energy demand increase. Thus, if these animals are not fed diets rich in energy, they start to mobilize large amounts of fat and they can develop metabolic problems, such as toxemia of pregnancy (MACEDO JUNIOR, 2008). In this sense, it has been proposed to use diets rich in fats to increase energy consumption in this phase, considered critical within the sheep production system.

Lipids have a higher energy value than any other nutrient, besides being the most important source of energy reserve for animals (NATIONAL RESEARCH CONCIL, 2007). The substitution of non-fibrous carbohydrates for lipids prevents the formation of lactic acid and the high production of volatile fatty acids in the rumen (VAN SOEST, 1994). However, its addition to the diet can alter rumen fermentation and decrease fiber digestibility (JENKINS et al., 2008), making it necessary to attend to the ether extract (EE) amount in diets for ruminants. In research by Millen et al. (2009), the average EE content was 4.7\%. Similar to this result, Oliveira and Millen (2014) observed an average 4.6\% EE content in diets, while Pinto and Millen (2016) reported that confinement diets have an average of 5\% EE. Unsaturated fatty acids are considered toxic to the ruminal microbiota. This toxicity may be related to the lipid's ability to disrupt the structure of cell membranes. However, ruminal microorganisms make use of biohydrogenation, converting unsaturated to saturated fatty acids, placing hydrogen in the carbon chain, and making them less toxic (PALMQUIST \& MATTOS, 2006). Therefore, one way of having the benefit of using lipids without damaging the rumen environment and obtaining higher levels of $\mathrm{EE}$ in the diet would be to use protected fat. 
Another strategy used to reduce the negative effects of lipids on ruminal fermentation is the use of oilseeds, such as cottonseed, once the fatty acid sources of these products are partially protected from ruminal degradation (OLIVEIRA et al., 2011). Bearing that in mind, the way fat is also offered alters the harmful effects of the rumen, since fatty acids in oilseed grains (cottonseed, soybeans, sunflower, peanuts, among others) become less problematic than the direct intake from the oil of these oilseeds, as they are protected by the seed structures and released more slowly (SILVA et al., 2014).

The paper hypothesizes the use of these fat sources in relation to soluble carbohydrate might improve the productive, nutritional, and metabolic performance of pregnant ewes, from the middle and final thirds. In this context, the objective is to evaluate fat sources with different degradation profiles in pregnant sheep diet on intake, ingestive behavior and productive performance.

\section{Material and methods}

The experiment was conducted at Capim Branco experimental farm at Federal University of Uberlândia, at goat and sheep sector, from August to November 2015. The experimental protocol for this work was approved by Ethics Committee on the Use of Animals (CEUA) - Universidade Federal de Uberlândia (UFU) under number 174/16. Twenty-four crossbred Santa Inês ewes (vaccinated (clostridiosis, leptospirosis and botulism) and dewormed (Monepantel) were used, average age over $12 \pm 1$ months and average body weight $50.8 \pm 0.7 \mathrm{~kg}$, at the beginning of the experimental period.

Before the experimental period, they were synchronized with the use of hormones (prostaglandin in a single application) and covered by natural mounts with Dorper male. After pregnancy confirmation (30 days after covering), by ultrasound, the sheep were kept in paddocks $\left(800 \mathrm{~m}^{2}\right)$ with 
Urochloa brizantha cv Marandu grass pasture from June to August (up to 60 days of pregnancy), receiving protein and energy supplement, in the form of protein, as well as availability of water and artificial shade. During this period, precipitation $(\mathrm{mm})$, humidity (\%) and maximum and minimum temperatures $\left({ }^{\circ} \mathrm{C}\right)$ averages were 8.2, 60.0, 26.7 and 16.8, respectively.

Experimental evaluations began from approximately 60 days of pregnancy until birth ( \pm 147 days of pregnancy). The animals were confined in three slatted floor pens, eight animals in each pen, with availability of mineral salt, external trough, and plastic drum drinker (cleaned and replaced every day). They went through the standard weighing, identification, deworming procedure and were subsequently drawn to treatments.

Three treatments were used: control (without fat source), palm oil protected fat and whole cottonseed in the concentrate. As roughage, corn silage was used. The diet was provided twice a day ( 8 am and $4 \mathrm{pm}$ ). The rations were balanced according to NRC (2007) for pregnant ewes. Initially for sheep up to 120 days of pregnancy and then adjusted as recommended by NRC 2007 for final third (last 30 days). They were composed of corn silage, corn bran, soy bran, different sources of fat and mineral mixture specific for ovine species. The roughage: concentrate ratio was $60 \%$ : 40\%, respectively. The composition of the concentrates is shown in Table 1.

Table 1. Ingredients and their proportions in experimental concentrates (\%)

\begin{tabular}{cccc}
\hline Ingredients & Control & Palm oil protected fat & Cottonseed \\
\hline Corn meal & 73,40 & 65,32 & 68,60 \\
Soybean meal & 24,60 & 24,68 & 19,40 \\
Mineral salt & 1,0 & 4,0 & 2,0 \\
Urea & 1,0 & 1,0 & 1,0 \\
Protected palm fat & - & 5,0 & - \\
Cottonseed & - & - & 9,0 \\
\hline \multicolumn{2}{c}{ Fatty acid profile of palm oil protected fat and cottonseed ${ }^{*}$} \\
\hline Fatty acids (\%) & Palm oil protected fat ${ }^{1}$ & Cottonseed
\end{tabular}




\begin{tabular}{cccc}
\hline Oleic & $18: 1$ & 27,98 & 15,50 \\
Linoleic & $18: 2$ & 38,27 & 55,50 \\
Linolenic & $18: 3$ & 3,04 & 2,10 \\
\hline Saturated & & 25,80 & 42,72 \\
Unsaturated & & 74,20 & 57,28 \\
Polyunsaturated & & 41,30 & 10,95 \\
Monounsaturated & & 32,90 & 46,33 \\
\hline
\end{tabular}

*Fonte: FEA Unicamp e PESCE, $2008 ;{ }^{1}$ Dados fornecidos pelo fabricante.

Due to the great feed supply offer, $10 \%$ of the total was left, with consumption adjusted by the change in live weight of the sheep every 21 days. Every day, in the morning, they were weighed as leftover feed and noted to calculate the average animal's intake in each pen. For that, leftover samples from each bay and reduced silage were taken daily. Then, at the end of each week, a sample was made up of each treatment and reduced silage.

Subsequently, the samples were first dried in oven with forced air circulation, at $65^{\circ} \mathrm{C}$ for 72 hours, until constant weight was obtained. Afterwards, the samples were crushed, in Willey knife mill, in $1 \mathrm{~mm}$ particles. Soon after, the samples were taken to the laboratory where the second sample material was made, in oven at $105^{\circ} \mathrm{C}$ for 24 hours, being possible to calculate their definitive dry matter (LENKEIT \& BECKER, 1956). Thus, it was possible to estimate the dry matter intake (DMI) per pen weekly, generating a graph with each pen intake for comparison. Intake was obtained by the difference between the amount of offered feed and subtracted by leftovers after 24 hours.

The biometric measurement of barrel circumference (BC), given in $\mathrm{cm}$, was measured with the aid of a tape measure. The contour of the abdominal cavity is read from the bottom to the ribs where the void of the animal is located. The body condition score (BCS) was performed by a single trained evaluator by palpating the lumbar vertebrae, allowing the assessment of fat 
deposition in the animal, according to the method described by Russel et al. (1969), in which 1- very thin; 2- lean; 3- normal; 4- fat; 5- obese. WeiHeng® digital scales with an accuracy of 10 grams were used to assess the animals' weight. Biometric measurements and animal weighing were performed at 0 , 21, 42 and 63 days (60, 81, 102 and 123 days of pregnancy), with weighing and biometrics being performed in the morning (8:00 am), before providing feed. The analyses were performed until the beginning of final third (123 days) in order not to stress the animal once they were pregnant and the stress could lead to abortions.

Ingestive behavior assessment was performed only once, at 60 days of experiment (120 days of pregnancy). The animals were analyzed for twentyfour hours by trained people surveillance, in a relay system, arranged so as not to disturb the animals. At night, the environment received artificial lighting, and the lights were kept on for five days before the evaluation to promote the animals' adaptation. It was verified, every five minutes, if the animals were fed supplements, water, or mineral salt (FEED), ruminating (RUM) or idling (IDLE), according to the methodology proposed by Fischer et al. (1998). The total time spent on chewing (CHEW) was determined by adding the times spent on intaking (INT) and rumination (RUM).

Before birth (approximately five days) the animals were taken to the floor pens. Right after birth, the sheep were weighed with the aid of an electronic scale and after weighing, the following measurements were taken: BCS and BC of the mother and weight of the lamb. Sheep blood was also collected by venipuncture of the jugular with the aid of vacuntainner and tubes without anticoagulant. Soon after, each animal samples were centrifuged, pipetted, and stored in eppendorfs ${ }^{\circledR}$ cryotubes for further laboratory analysis using a commercial kit from Lab Test ${ }^{\circledR}$. The determined energy metabolites were: cholesterol (mg / $\mathrm{dL}$ ), triglyceride (mg / dL), HDL (high density lipoprotein) (mg / dL), fructosamine $(\mathrm{mg} / \mathrm{dL}$ ) and glucose $(\mathrm{mg} / \mathrm{dL})$. The VLDL (very low- 
density lipoprotein) (mg / dL) and LDL (low density lipoprotein) (mg / dL) lipoproteins were later calculated using the formula proposed by Friedwald et al. (1972), in which LDL = total cholesterol - (HDL + VLDL), where the concentration of VLDL was estimated through the serum concentration of triglycerides $(\mathrm{VLDL}=($ triglyceride $/ 5))$. The hepatic metabolites were: aspartate aminotrasferase ( $\mathrm{U} / \mathrm{L})$, gamma glutamyltranferase (U/L) and alkaline phosphatase (U / L). The protein metabolites were albumin $(\mathrm{g} / \mathrm{dL})$, total protein $(\mathrm{g} / \mathrm{dL})$, creatinine $(\mathrm{mg} /$ $\mathrm{dL})$, urea $(\mathrm{mg} / \mathrm{dL})$ and uric acid $(\mathrm{mg} / \mathrm{dL})$. Moreover, the relationship between the average weight of the offspring (AWO) and the total weight of the offspring (TWO) with the mother's weight (MW) was measured.

Data normality and residual tests by W and D statistics (Shapiro \& Wilk, 1965; Lilliefors 1967) and homoscedasticity of treatment variances (Levene, 1960) were performed. A completely randomized design was used (this procedure was used to make the experimental groups with initial weight and BCS more homogeneous. However, afterwards, a draw was carried out between the treatments, which guaranteed equal probability of each individual falling into any of treatments) with three treatments: control, palm oil protected fat and cottonseed, and eight repetitions, the periods being evaluated as repeated measures over time. For the variables in which the sphericity condition was not accepted, we used the mixed model analysis, in which all covariance structures $(\Sigma)$ available in the SAS software package [(ANTE (1)) - Anti- Dependence; (AR (1)) - First order autoregressive; (ARH (1)) - Heterogeneous firstorder autoregressive; (ARMA (1.1)) - First order autoregressive moving average; (CS) - Composite symmetry; (CSH) - Heterogeneous composite symmetry; (FA (q)) - Analytical factor; (FA0 (q)) - Non-diagonal analytical factor; (FA1 (q)) - Analytical factor equal to diagonal; (HF) - Huynh-Feldt; (LIN (q)) - General Linear; (PSC) - Classic subdivided portion; (TOEP) Toeplitz; (TOEP (q)) - United Toeplitz; (TOEPH (q)) - United 
heterogeneous toeplitz; (TOEPH) - Toeplitz heterogeneous; (UN (q)) unstructured joined; (UN) - unstructured; (UN @ AR (1)) - Unstructured first order autoregressive of direct product; (UN @ CS) - Unstructured composite symmetry of direct product; (UN@UN) - unstructured direct product; (UNR (q)) - Unstructured correlations united; (UNR) Unstructured correlations; (VC) - Component of variance] (SAS INSTITUTE, 2012) which shape the dependence of model errors. Akaike information criterion (AIC) was used to select the covariance structure that best explains the residual correlation, and the structure that resulted in the lowest AIC value after analysis was chosen for each variable (SILVA et al., 2015).

Treatments means were evaluated by t-student test, according to criteria established by Sampaio (2002) and the periods by means of linear regression analysis in which the significance of the model (linear or quadratic) was observed, the significance of the coefficients, the nonsignificance of the deviations from linearity and the highest R2, with these first two criteria evaluated at level of significance of 5\% probability of type I error. The bays were used as repetition to evaluate dry matter consumption, once there is no repetition of stalls. The body condition score variable, as it is a non-parametric variable, was assessed by using the Kruskal and Wallis (1952) test, with 5\% significance level of probability of type I error.

\section{Results and discussion}

Dry matter intake (DMI) increase was observed up to 137 days of pregnancy (Graph 1) in all treatments. However, after this period until birth, there was an already expected reduction once animals on the final stage of pregnancy suffer physical influences (ruminal compression) due to the rapid growth of the pregnant uterus and hormonal influences. According to Macedo Junior et al. (2010), the demand for nutrients by the fetus during 
pregnancy increases progressively, as does the volume it occupies in the abdominal cavity. The exact mechanism consumption is inhibited by this smaller ruminal space is not known and it may be related to discomfort in the gastrointestinal tract (VAN SOEST, 1994).

Graph 1. Dry matter intake according to the week per pen

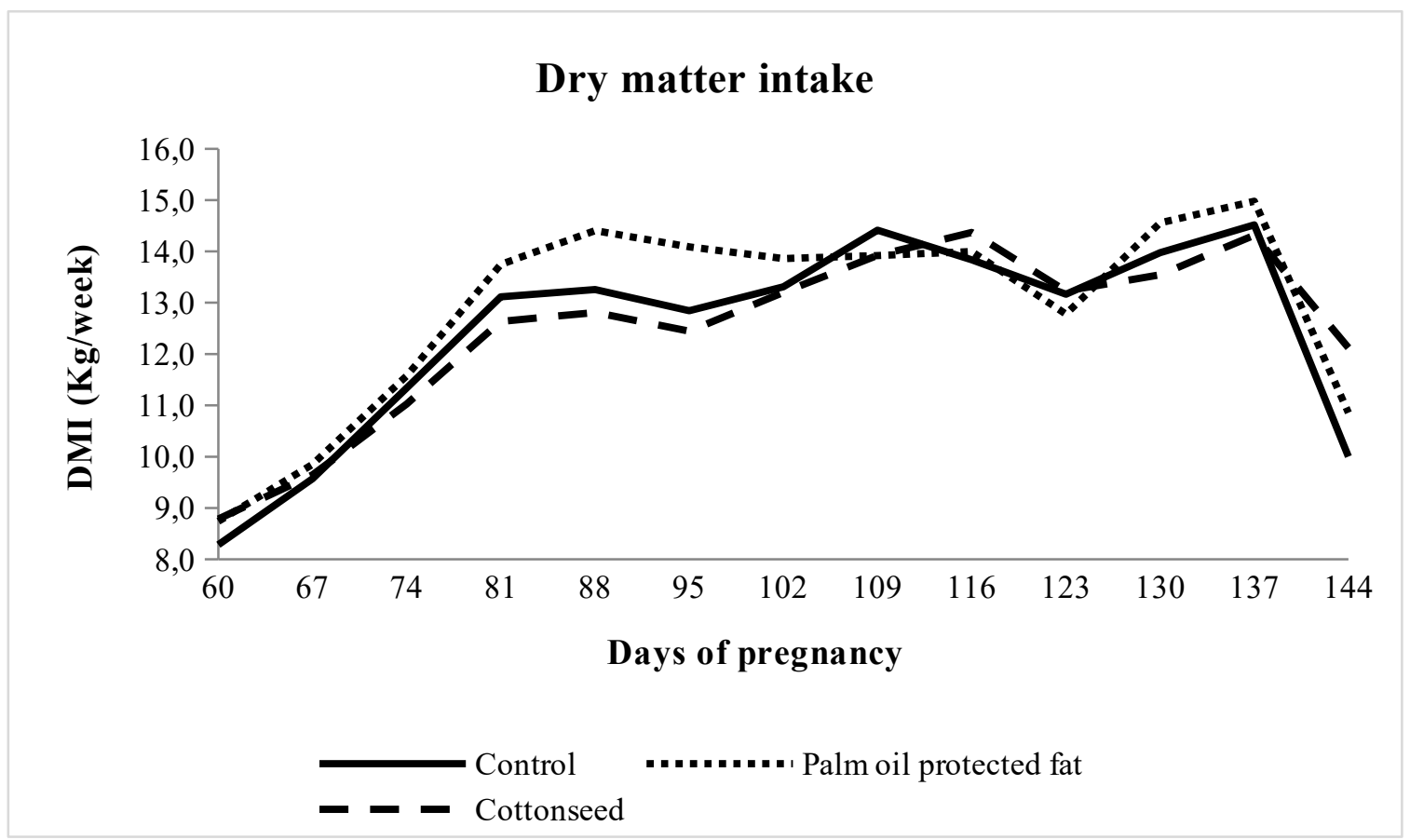

There are some points of oscillation (in all treatments), which is normal, and points of oscillation may be related to the change in the animal's nutritional requirement. According to NRC (2007), sheep pregnancy is divided into two phases: 0-120 days and 120-150 days. At first, fetal growth is exceedingly small, and it does not cause changes in the animal's metabolism, keeping the animal's requirements remarkably close to the maintenance requirements. The last 30 days are marked by fetus exponential growth, which implies major changes in maternal metabolism. In this phase, the demands on energy, protein, minerals, water, and other nutrients increase significantly, increasing the DMI, which is seen in Graph 1. DMI decreasing near birth is normal and it may be related to fat 
mobilization from adipose tissue, because of low energy intake once the energy of the diet was not increased close to delivery. It is also associated with uterine volume growth. It is important to highlight that at 123 days of pregnancy, the exact moment of the change suggested by NRC (2007), the animals showed a sharp drop in the DMI and then increased DMI again until 137 days of pregnancy. This moment seems to indicate some physiological change not yet elucidated.

Furthermore, oscillations may also be related to roughage supplied quality. Depending on the pregnancy stage and the number of fetuses, care must be taken with the food type provided, especially regarding roughage. Very fibrous foods that require a longer fermentation time can reduce consumption by sheep. In this sense, Macedo Junior et al. (2009) increased roughage levels in the diet of pregnant ewes and they concluded that the maximum roughage point in the animal diet should be $35 \%$ in order not to reduce the consumption of dry matter and, consequently, energy and protein. In addition, the minimum point should be $20 \%$ of fiber in neutral detergent in forage (NDF), for better efficiency in the nutrient usage. In the present study, roughage represented $40 \%$ of the animals' diet (48\% of fiber in total neutral detergent). It is inferred this fluctuation in DMI may be partially explained by this factor. It is important to note that these consumption data are descriptive.

There was no change in body weight (BW) and body condition score (BCS) as a result of treatments. Body weight increased significantly with advancing pregnancy (Table 2); it is possible due to the increase in DMI at this stage (Graph 1). As previously stated, until 120 days of pregnancy, these animals keep their requirements remarkably close to those of maintenance, which implies low energy expenditure with other activities (fetal growth and milk production), and, therefore, all energy consumed is basically for the animal, reflecting the increase in body weight until 123 days (Table 2). It is expected that pregnancy advancement (after 120 days) 
these animals will increase body weight, mainly due to the weight increase of the pregnant uterus. Ewes in the final third of pregnancy reach $70 \%$ increase in the rate of fetal growth (PILAR et al., 2002).

Table 2. Effect of different fat sources on average body weight (kg), body condition score (BCS), average daily gain ( $\mathrm{g} /$ day) and barrel circumference $(\mathrm{cm})$ of pregnant ewes on the treatments and pre-birth gestational period

\begin{tabular}{|c|c|c|c|c|c|c|c|}
\hline \multirow[b]{2}{*}{ Item } & & \multicolumn{3}{|c|}{ Treatments } & \multirow[b]{2}{*}{$\mathrm{P}$-value } & & \\
\hline & & Control & $\begin{array}{c}\text { Palm oil } \\
\text { protected fat }\end{array}$ & $\begin{array}{c}\text { Cottonsee } \\
\text { d }\end{array}$ & & & \\
\hline BW & & 58,87 & 61,53 & 61,36 & 0,3698 & & \\
\hline BCS & & 3,28 & 3,06 & 3,08 & 0,4589 & & \\
\hline \multirow{2}{*}{ Item } & \multicolumn{4}{|c|}{ Period } & \multirow{2}{*}{$\mathrm{P}$-value } & \multirow{2}{*}{ GA } & \multirow{2}{*}{$\mathrm{CV}$} \\
\hline & $0(60)$ * & $21(81)$ & $42(102)$ & $63(123)$ & & & \\
\hline $\mathrm{BW}^{1}$ & 50,81 & 56,49 & 63,65 & 70,20 & 0,6214 & 60,92 & 6,97 \\
\hline BCS & $2,80 \mathrm{~B}$ & $2,89 \mathrm{~B}$ & $3,25 \mathrm{~A}$ & $3,54 \mathrm{~A} 1$ & 0,0023 & 3,14 & $\mathrm{xxx}$ \\
\hline \multicolumn{8}{|c|}{ Interaction Treatment $\mathrm{x}$ Period $-\mathrm{BC}(\mathrm{GA}=112,15 \mathrm{~cm} ; \mathrm{CV}=4,97 \%)$} \\
\hline & $0(60) *$ & $21(81)$ & $42(102)$ & $63(123)$ & $\mathrm{P}$-value & & \\
\hline Control $^{2}$ & 109,50 & 111,00 & 115,62 & 118,75 & 0,0014 & & \\
\hline $\begin{array}{c}\text { Palm oil } \\
\text { protected fat }\end{array}$ & 107,66 & 109,62 & 113,70 & 118,37 & 0,0289 & & \\
\hline Cottonseed & 106,50 & 108,00 & 106,25 & 117,62 & 0,0347 & & \\
\hline \multicolumn{8}{|c|}{ Average daily gain (g/dia) } \\
\hline \multirow{2}{*}{\multicolumn{2}{|c|}{ Period }} & \multicolumn{3}{|c|}{ Treatments } & \multirow[b]{2}{*}{ P-value } & \multirow[b]{2}{*}{ GA } & \multirow[b]{2}{*}{$\mathrm{CV}$} \\
\hline & & Control & $\begin{array}{c}\text { Palm oil } \\
\text { protected fat }\end{array}$ & $\begin{array}{c}\text { Cottonsee } \\
\mathrm{d}\end{array}$ & & & \\
\hline $0-21$ & & 472,22 & 322,81 & 319,29 & 0,8859 & $\begin{array}{c}371,4 \\
4\end{array}$ & $\begin{array}{c}31,8 \\
9\end{array}$ \\
\hline $0-42$ & & 369,64 & 393,74 & 301,48 & 0,7821 & $\begin{array}{c}354,9 \\
5\end{array}$ & $\begin{array}{c}34,3 \\
6\end{array}$ \\
\hline $21-42$ & & 307,14 & 414,88 & 300,59 & 0,3698 & $\begin{array}{c}340,8 \\
7\end{array}$ & $\begin{array}{c}36,5 \\
6\end{array}$ \\
\hline $0-63$ & & 354,96 & 341,37 & 287,69 & 0,4789 & $\begin{array}{c}328,0 \\
1\end{array}$ & $\begin{array}{c}27,2 \\
3\end{array}$ \\
\hline $42-63$ & & 326,16 & 267,26 & 343,45 & 0,2258 & $\begin{array}{c}312,3 \\
0\end{array}$ & $\begin{array}{c}21,5 \\
7\end{array}$ \\
\hline
\end{tabular}




\begin{abstract}
Means followed by different letters in the lines differ from each other (The treatment means were evaluated by the t-student test at the level of significance of $5 \%$ probability of type I error); * Values within the parentheses represent the gestational period of the sheep; BW: body weight; BCS: body condition score; GA: general average; CV: coefficient of variation; ${ }^{1} \mathrm{X}=50,49+0,31 \mathrm{X} \mathrm{R}^{2}=99,81 \%$; ${ }^{2} \mathrm{Y}=$ $108,86+0,157 \mathrm{X} \mathrm{R}^{2}=96,80 \% ;{ }^{3} \mathrm{Y}=106,92+0,17 \mathrm{X} \mathrm{R}^{2}=97,17 \% ;{ }^{4} \mathrm{Y}=107,32-0,20 \mathrm{X}+0,005 \mathrm{X}^{2} \mathrm{R}^{2}=$ $84,73 \%$.
\end{abstract}

The animals increased body condition score (BCS) with pregnancy advancement (up to 123 days), which may be related to the fact that they are confined, consequently spending little energy. In addition, there was increase in DMI up to 123 days of pregnancy. It is expected with the pregnancy advance (after 120 days) the sheep will reduce BCS due to higher energy demand and reduced consumption. It is noteworthy general average of BCS in the pre-birth period (3.14) was similar that values described in literature, from 2.5 to 4.0 (SÁ \& OTTO DE SÁ, 2001). It is extremely important to control BCS in herd, as it provides us with easy and reliable method of estimating the animal nutritional status.

There was a linear increase in barrel circumference (BC) with experimental period advancement (Table 2) for animals that received the control treatment and palm oil protected fat. Animals that received cottonseed there was a quadratic increase. The increase, in both treatments, is related with period measured (123 days), where fetal growth is low and, therefore, these animals increased their consumption capacity (Graph 1) and consequently increased their body weight at the same period.

There is no statistical difference in relation to average daily gain (ADG) of sheep, indicating that both treatments presented the same ADG throughout the experimental period (Table 2). We can say that for the variables discussed above, all treatments showed similar results, once there were no statistical differences amid them. Thus, the different sources of lipids in relation to soluble carbohydrate (control) do not improve the performance characteristics of pregnant sheep measured so far.

The animals that received cottonseed had a longer time in chewing and eating (Table 3), which can be explained by the seed grain was supplied 
whole (with linter), allowing for selection or rejection by this ingredient which caused the longest feeding time. Additionally, less idle time was observed in these animals compared with other treatments. Although cottonseed was supplied as a concentrate for these animals, linter (cellulose fibers) contained in it, gives it characteristics of bulky food (> 18\% FB, ANDRIGUETTO et al., 1982). The fibers ability to stimulate rumination is called "effectiveness". According to Van Soest (1994), the time spent on rumination is proportional to the cell wall content of bulky foods, with the effectiveness of fiber being a major factor in stimulating chewing, which explains why this treatment has a longer time in chewing than too much.

Table 3. Effect different fat sources on the average time spent on feeding, idle, rumination and total chewing ( $\mathrm{min} /$ day) in pregnant ewes.

\begin{tabular}{|c|c|c|c|c|c|c|}
\hline \multirow[b]{2}{*}{ Item } & \multicolumn{3}{|c|}{ Treatments } & \multirow[b]{2}{*}{$\mathrm{P}$-value } & \multirow[b]{2}{*}{ GA } & \multirow[b]{2}{*}{$\mathrm{CV}$} \\
\hline & Control & $\begin{array}{c}\text { Palm oil } \\
\text { protected fat }\end{array}$ & $\begin{array}{c}\text { Cottonsee } \\
\mathrm{d}\end{array}$ & & & \\
\hline Feeding & $154,37 \mathrm{~B}$ & $148,12 \mathrm{~B}$ & $209,37 \mathrm{~A}$ & 0,0014 & 170,62 & 25,59 \\
\hline Idle & $1068,75 \mathrm{~A}$ & $1028,75 \mathrm{~A}$ & $920,00 \mathrm{~B}$ & 0,0258 & 1005,83 & 9,82 \\
\hline $\begin{array}{c}\text { Ruminatio } \\
\mathrm{n}\end{array}$ & 216,87 & 240,62 & 310,62 & 0,8896 & 256,04 & 34,03 \\
\hline Chewing & $371,25 \mathrm{~B}$ & 388,75 B & $520,00 \mathrm{~A}$ & 0,0023 & 426,66 & 21,57 \\
\hline
\end{tabular}

Means followed by different letters in the lines differ (The treatment means were evaluated by the t-student test at the level of significance of $5 \%$ probability of type I error); GA: general average; $\mathrm{CV}$ : coefficient of variation.

There was no significant effect of fat source on rumination time (Table 3 ), which may be related to the roughage: concentrate ratio in the diet, which is the same for all treatments (60:40). According to Macedo Junior (2004) the rumination time increases with the increase in total NDF and NDF levels of diets, indicating a close link between the total NDF consumption and the rumination time. The time spent on rumination depends on the diet type and there seems to be little variation in diets rich in grains, reaching a maximum of 10 hours / day in those rich in roughage (QUEIROZ et al., 2001). In this study, 
the average time spent with rumination was 256.04 minutes / day, equivalent for 4 hours and 16 minutes.

According to Benevides et al. (2011), the time spent on rumination increases with advancing pregnancy. The same authors stated that at 130 days of pregnancy, sheep spent more time ruminating, compared with those at 90 and 110 days, perhaps because in this phase there is better ruminal compression effect due to higher uterus volume uterus and attachments. Thus, we can conclude that the animals in the present study did not spend much time ruminating, precisely because they are in the transition period (120 days) between two stages of pregnancy. The ability to feed and the feeding behavior are the result of integration amid several factors related to diet, with the environment and the physiological stage of the animal, not being a single factor that controls the intake (BENEVIDES, 2011).

In Table 4 we can see the average weight of the offspring was 4.30 kg, 14\% higher than expected according to Ribeiro et al (2008). There were statistical differences amid the treatments for the average weight of the offspring, with lambs born from ewes that received cottonseed compared to those that received palm fat, mainly related to the type of lipid contained in the seed, causing the level to increase cholesterol levels in the same period (Table 6).

Taking the birth weight of $3.77 \mathrm{~kg}$ as reference (RIBEIRO et al, 2008), we can conclude that lambs born from sheep treated with cottonseed had higher than expected birth weight (27\%), which is related to higher cholesterol level at the farrowing time (Table 6), reflecting greater capacity for energy use by sheep. From the point of view of improving the herd's zootechnical indexes, higher birth weight is advantageous once heavier lambs have a higher survival rate, consequently lower mortality at weaning, higher weight at weaning and in future higher weight at slaughter (GERASSEV et al., 2006; CASTRO et al., 2012). It is important to note that very heavy and large lambs can also present disadvantages, especially at 
the time of birth, causing dysfunctional births (SCHAFHÄUSER et al., 2004). In that study, the sheep did not present difficulties at the time of farrowing, indicating that the lambs were not too large and heavy to the point of distortion.

Table 4. Effect of different fat sources on barrel circumference $(\mathrm{cm})$, weight of mothers $(\mathrm{kg})$, weight of average offspring $(\mathrm{kg})$, total weight of offspring $(\mathrm{kg})$ and the relationship between average offspring weight and weight total of offspring with mothers' weight (\%) at birth in pregnant ewes

\begin{tabular}{|c|c|c|c|c|c|c|}
\hline \multirow[b]{2}{*}{ Item } & \multicolumn{3}{|c|}{ Treatments } & \multirow[b]{2}{*}{ P-value } & \multirow[b]{2}{*}{ GA } & \multirow[b]{2}{*}{$\mathrm{CV}$} \\
\hline & Control & $\begin{array}{c}\text { Palm oil } \\
\text { protected } \\
\text { fat }\end{array}$ & $\begin{array}{c}\text { Cottonsee } \\
\mathrm{d}\end{array}$ & & & \\
\hline MW & 55,96 & 66,30 & 65,48 & 0,5569 & 61,89 & 16,09 \\
\hline $\mathrm{BC}$ & 107,80 & 108,00 & 110,20 & 0,3647 & 108,76 & 10,18 \\
\hline AWO & $4,12 \mathrm{AB}$ & 3,77 B & $4,79 \mathrm{~A}$ & 0,0027 & 4,30 & 13,42 \\
\hline TWO & 5,72 & 6,05 & 6,48 & 0,1896 & 6,09 & 32,47 \\
\hline AWO/MW & 7,64 & 5,73 & 7,36 & 0,4456 & 7,09 & 18,29 \\
\hline TWO/MW & 11,25 & 9,43 & 9,87 & 0,9987 & 10,30 & 34,71 \\
\hline
\end{tabular}

Means followed by different letters in the lines differ from each other (The treatment means were evaluated by the t-student test at the significance level of $5 \%$ probability of type I error); MW: mother's weight; BC: circumference of the mother's barrel; AWO: average weight of the offspring; TWO: total weight of the offspring; GA: general average; CV: coefficient of variation.

For the other variables, there were no statistical differences, being similar for both treatments. Regarding the relationship between the weight of the offspring and their mothers, the greater the relationship, the better, indicating the availability of nutrients was sufficient to cause good offspring growth. Moreover, the average fetal weight corresponded to approximately $7.09 \%$ of maternal weight. In some cases, it may generate consumption restrictions due to the space occupied by pregnant uterus in abdominal cavity, which ends up compressing the gastrointestinal tract. Therefore, it may affect the animal's performance, as seen in the present study (Graph 1), once DMI decreased (descriptive data) until birth, demonstrating consumption restriction at this stage. 
Regarding protein metabolites at birth, there is statistical difference amid treatments only for the variable creatinine (Table 5).

Table 5. Average protein metabolites of ewes at birth

\begin{tabular}{|c|c|c|c|c|c|c|c|}
\hline \multirow[b]{2}{*}{ Item } & \multicolumn{3}{|c|}{ Treatments } & \multirow[b]{2}{*}{$R V^{*}$} & \multirow[b]{2}{*}{$\begin{array}{c}\mathrm{P} \text { - } \\
\text { value }\end{array}$} & \multirow[b]{2}{*}{ GA } & \multirow[b]{2}{*}{$\mathrm{CV}$} \\
\hline & $\begin{array}{c}\text { Contr } \\
\text { ol }\end{array}$ & $\begin{array}{c}\text { Palm oil } \\
\text { protected } \\
\text { fat }\end{array}$ & $\begin{array}{c}\text { Cottonsee } \\
\text { d }\end{array}$ & & & & \\
\hline $\begin{array}{l}\text { Uric acid } \\
m g / d L\end{array}$ & 0,22 & 0,12 & 0,08 & $0,1-0,9$ & $\begin{array}{c}0,774 \\
8\end{array}$ & 0,14 & 20,80 \\
\hline $\begin{array}{l}\text { Albumin } \\
m g / d L\end{array}$ & 3,59 & 3,69 & 4,15 & $1,56-5,01$ & $\begin{array}{c}0,558 \\
9\end{array}$ & 3,80 & 15,65 \\
\hline $\begin{array}{c}\text { Creatinine } \\
\text { mg/dL }\end{array}$ & $0,47 \mathrm{~B}$ & $0,46 \mathrm{~B}$ & $0,72 \mathrm{~A}$ & $0,2-1,5$ & $\begin{array}{c}0,000 \\
1\end{array}$ & 0,54 & 22,03 \\
\hline $\begin{array}{l}\text { Urea } \\
\qquad m g / d L\end{array}$ & 29,58 & 23,60 & 27,00 & $7,0-55,8$ & $\begin{array}{c}0,881 \\
1\end{array}$ & 26,90 & 34,55 \\
\hline $\begin{array}{c}\text { Total Proteins } \\
\qquad g / d L\end{array}$ & 5,72 & 5,52 & 5,30 & $2,26-7,18$ & $\begin{array}{c}0,694 \\
5\end{array}$ & 5,52 & 10,08 \\
\hline
\end{tabular}

Means followed by different letters in the lines differ from each other (The treatment means were evaluated by the t-student test at the significance level of $5 \%$ probability of type I error); * (Varanis, 2018); GA: general average; CV: coefficient of variation; RV: reference values.

The creatinine value was lower in the control and palm oil protected fat treatments, probably because these animals spent more time in leisure (Table 3). They spent less time-consuming energy by the muscle. Low levels of creatinine are related to renal failure and degenerative muscle changes (GONZÁLEZ \& SILVA, 2006). Bearing in mind that these animals did not present any renal alteration, we can emphasize that what caused lower levels of creatinine was the moment of birth, once the number of movements performed is reduced. Moreover, it is emphasized that the general average of this metabolite is within the value recommended by Varanis (2018) for pregnant sheep.

The variables uric acid and urea are within the reference values (VARANIS, 2018). It appears that the average value of albumin and total 
proteins are within the recommended by Varanis (2018), indicating that there was adequate protein consumption by animals. Furthermore, according to the results presented, these animals were efficient from the protein point of view at birth, indicating good nutritional status.

For energy metabolites at birth, statistical differences amid treatments are observed only for the cholesterol variable (Table 6). The highest cholesterol values were observed in the animals that received the treatment with Cottonseed. It is inferred that the type of lipid contained in the cottonseed may have caused this result (Table 1). Cottonseed addition increases the saturated fatty acids concentration and decreases unsaturated fatty acids, due to the extensive biohydrogenation that occurs in rumen (EZEQUIEL, 2001), which stimulates higher cholesterol production for formation of lipoproteins.

Table 6. Average energy and hepatic metabolites of ewes at birth

\begin{tabular}{|c|c|c|c|c|c|c|c|}
\hline \multirow[b]{2}{*}{ Item } & \multicolumn{3}{|c|}{ Treatments } & \multirow[b]{2}{*}{$\mathrm{RV}^{*}$} & \multirow{2}{*}{$\begin{array}{c}\mathrm{P}- \\
\text { value }\end{array}$} & \multirow[b]{2}{*}{ GA } & \multirow[b]{2}{*}{ CV } \\
\hline & Control & $\begin{array}{c}\text { Palm oil } \\
\text { protected fat }\end{array}$ & Cottonseed & & & & \\
\hline $\begin{array}{c}\text { Cholesterol } \\
m g / d L\end{array}$ & 58,45 B & $68,60 \mathrm{AB}$ & $76,40 \mathrm{~A}$ & $13-117$ & 0,0025 & 67,23 & 17,73 \\
\hline $\begin{array}{l}\text { HDL } m g / \\
d L\end{array}$ & 9,91 & 12,40 & 13,40 & $7-42$ & 0,7489 & 11,78 & 33,87 \\
\hline $\begin{array}{c}\text { LDL } m g / \\
d L\end{array}$ & 45,70 & 52,48 & 59,32 & $4,3-95,5$ & 0,5698 & 52,09 & 23,65 \\
\hline $\begin{array}{l}\text { VLDL } \\
m g / d L\end{array}$ & 2,79 & 3,72 & 3,68 & $1,6-9,8$ & 0,6102 & 3,35 & 36,64 \\
\hline LDL/HDL & 5,95 & 6,67 & 4,73 & & 0,1478 & 5,79 & 34,10 \\
\hline CT/HDL & 7,28 & 8,09 & 6,01 & & 0,7858 & 7,14 & 34,23 \\
\hline $\begin{array}{l}\text { Triglycerid } \\
\text { es } m g / d L\end{array}$ & 13,95 & 18,60 & 18,40 & $9-47$ & 0,4789 & 16,79 & 36,64 \\
\hline $\begin{array}{l}\text { Glucose } \\
m g / d L\end{array}$ & 77,40 & 90,60 & 75,16 & $29-59$ & 0,8847 & 80,68 & 30,07 \\
\hline Fructosami & 164,33 & 164,88 & 177,60 & $172 \pm 2^{* *}$ & 0,4893 & 168,62 & 7,78 \\
\hline
\end{tabular}


ne $\mu \mathrm{mol} / \mathrm{L}$

$\begin{array}{cccccccc}\text { AST } & 120,91 & 85,00 \mathrm{~B} & 121,40 \mathrm{~A} & 45-251 & 0,0029 & 109,84 & 25,76 \\ \mathrm{U} / \mathrm{L} & \mathrm{A} & & & & & & \\ \mathrm{GGT} & 98,79 & 91,40 & 86,40 & 28-104 & 0,1258 & 92,60 & 39,75 \\ \mathrm{U} / \mathrm{L} & & & & & & & \\ \mathrm{AP} & 119,20 & 132,40 & 125,80 & 33-331 & 0,2549 & 125,39 & 34,21 \\ \mathrm{U} / \mathrm{L} & & & & & & & \end{array}$

Means followed by different letters on the different lines between them (As the control media were assessed by the student's test at the $5 \%$ significance level of type I error probability); * (Varanis, 2018); ** (Kaneko et al., 2008); AP: alkaline phosphatase; GA: general average; CV: coefficient of variation; RV: reference values.

It appears that the average HDL value is within the range recommended by Varanis (2018). HDL's role is to remove excess cholesterol from the tissues, guiding it to the liver, where it will be metabolized, generating energy for animal (LIMA et al., 2006). As for the fructosamine variable, used to monitor glycemia in pregnant women with diabetes during pregnancy (FEITOSA et al., 2014), an average value below (0.01\%) of that established by Kaneko et al. (2008), which we cannot affirm that there was effect at the time of birth.

The variables cholesterol, triglycerides and VLDL are within the reference values (VARANIS, 2018). Glucose overall average is $36.74 \%$ above that recommended by Varanis (2018). This increase is due to hormonal changes at the time of birth, mainly because it promotes gluconeogenesis. According to Vazquez-Añon et al. (1994) the plasma glucose concentration remains stable, or increases rapidly during the days close to birth, reaching its highest value on the day of birth and decreasing immediately in the postpartum period. In addition, another factor that may be related to this increase is stress, once glucose levels can be influenced by stress (GONZÁLEZ, 2000).

In general, energy metabolites are within the reference values, which may be related to the increase in DMI throughout the experimental period (Graph 1), providing less chances of pregnancy toxemia cases and adequate 
birth weight of the offspring (Table 4), indicating that these animals were energy efficient at birth.

Regarding hepatic metabolites at birth, there are statistical differences amid treatments only for the variable AST (Table 6). Enzyme Aspartate Aminotransferase (AST), when identified above the concentrations considered normal, indicates the animal may develop secondary hepatic-cellular damage, resulting from excessive lipid mobilization. However, in the present study, AST concentrations were within the range considered normal for the species (VARANIS, 2018), which indicates that these animals did not develop liver damage. It is noteworthy that the animals supplemented with palm oil protected fat showed the lowest value, probably related to the lipid type (inert). Fat digestion causes the liver to become overloaded, increasing AST level. However, the digestion of inert fat differs somewhat from the "traditional" one, as it passes through the rumen without causing major changes, which resulted in a lower AST value for treatment with protected palm fat.

For the variables alkaline phosphatase and GGT, their general averages are within the reference values (VARANIS, 2018), indicating that animals were efficient from the hepatic point of view and reinforces the result found, indicating that these animals did not develop any liver injury.

\section{Conclusion}

Cottonseed usage as a fat source increases the birth weight of the progeny and improves pregnant sheep metabolic profile in relation to inert fat. 


\title{
Fontes de gordura protegida e parcialmente protegida da degradação ruminal para ovelhas gestantes
}

\begin{abstract}
Resumo: As fontes de gordura representam importante componente na alimentação animal. Entretanto, os ruminantes não evoluíram para degradar de forma eficiente os lipídeos. Visto isso, é necessário estudar como a suplementação desses produtos pode afetar o desempenho dos animais. Objetivou-se avaliar a utilização de diferentes fontes de lipídeos para ovelhas gestantes sobre o consumo, desempenho, metabólitos e comportamento ingestivo. $\mathrm{O}$ experimento foi realizado na Fazenda Experimental Capim Branco, no setor de caprinos e ovinos da Universidade Federal de Uberlândia, durante os meses de agosto a novembro de 2015. Foram utilizadas 24 ovelhas gestantes com peso corporal médio de 50,8 $\pm 0,7 \mathrm{Kg}$ e idade aproximada de $12 \pm 1$ meses. Os animais foram divididos em três tratamentos (Controle, gordura protegida de óleo de palma e caroço de algodão). O volumoso utilizado foi a silagem de milho. A relação volumoso: concentrado foi de 60:40 (na matéria seca). As mensurações de peso corporal, escore corporal e medidas biométricas foram feitas a cada 21 dias. Foi realizada uma avaliação de comportamento ingestivo aos 120 dias de gestação. A mensuração do consumo foi feita de forma descritiva. Logo após o parto, as ovelhas e suas crias foram pesadas e feita a circunferência do barril e coletado sangue da mãe. O delineamento utilizado foi inteiramente ao acaso com medidas repetidas ao tempo. Foi verificado maior tempo gasto com alimentação e mastigação no tratamento com caroço de algodão e consequentemente menor tempo em ócio nesse tratamento. Não houve diferença estatística no peso, circunferência do barril (CB) e escore de condição corporal (ECC) das ovelhas nos diferentes tratamentos. Verificou-se crescimento linear nas medidas de $\mathrm{CB}$ e peso das ovelhas ao decorrer dos períodos avaliados. Houve diferença entre os tratamentos para o peso médio das crias. A utilização do caroço de algodão como fonte de gordura aumenta o peso ao nascimento da progênie e melhora o perfil metabólico de ovelhas gestantes em relação a gordura inerte.
\end{abstract}

Palavras-chave: Caroço de algodão, Gordura inerte, Nutrição, Ovis aries.

\section{References}

ANDRIGUETTO, J. M.; PERLY, L.; MINARDI, I.; GEMAEL, A.; FLEMMING, J. S.; SOUZA, G. A. de; BONA FILHO, A. Nutrição animal: as bases e os fundamentos da nutrição animal - os Alimentos, Vol. I, São Paulo: Nobel, 395p., 1982.

BENEVIDES, Y. I.; CAMPOS, W. E.; RODRIGUEZ, N. M.; MACEDO JUNIOR, G. L.; BORGES, I.; FERREIRA, M. I. C.; BRITO, T. S.; PIRES, C. P.; Comportamento 
ingestivo de ovelhas submetidas ou não à restrição nutricional durante a gestação. Archivos Zootecnia. Vol.60,2011. https://doi.org/10.4321/S0004-05922011000400006

CASTRO, F.A.B.; RIBEIRO, E.L.A.; MIZUBUTI, I. Y.; SILVA, L. D. F.; BARBOSA, M. A. A. F.; SOUSA, C. L.; PAIVA, F. H. P.; KORITIAKI, N. A. Influence of pre and postnatal energy restriction on the productive performance of ewes and lambs. Revista Brasileira de Zootecnia, Viçosa, v. 41, n. 4, p. 951-958, 2012. https://doi.org/ 10.1590/S1516-35982012000400017

FISCHER, V.; DESWYSEN, A. G.; DÈSPRES, L.; DUTILLEUL, P.; LOBATO, J. F. P. Padrões nectemerais do comportamento ingestivo de ovinos. Revista Brasileira de Zootecnia, v. 27, n. 2, p. 362-369, 1998.

FRIEDEWALD, W.T; LEVY, R.I; FREDRICKSON, D.S; Estimation of the concentration of low-density lipoprotein cholesterol in plasma, without use of the preparative ultracentrifuge. Clinical Chemistry. 18(6), 499-502, 1972. https://doi.org/10.1093/clinchem/18.6.499

GERASEEV, L. C. PEREZ, J. R. O. CARVALHO, P. A. et al. Efeitos das restrições pré e pós-natal sobre o crescimento e o desempenho de cordeiros Santa Inês do nascimento ao desmame. Revista Brasileira de Zootecnia, v.35, n.1, 2006. https://doi.org/10.1590/S1516-35982006000100031

GONZÁLEZ, F. H. D. Uso de perfil metabólico para determinar o status nutricional em gado de corte. In: GONZÁLEZ, F. H. D.; BARCELLOS, J. O.; OSPINA, H.; RIBEIRO, L. A. O. (Eds). Perfil metabólico em ruminantes: seu uso em nutrição e doenças nutricionais. Porto Alegre, Brasil. Gráfica da Universidade Federal do Rio Grande do Sul, 2000.

GONZÁleZ, F. H. D.; SILVA, S. C. Perfil Bioquímico no Exercício. In: GONZÁLEZ, F. H. D.; SILVA, S. C. Introdução à Bioquímica Clínica Veterinária. Porto Alegre: Universidade Federal do Rio Grande do Sul. 2006. 
JENKINS, T. C.; WALLACE, R. J.; MOSLEY E. E. Recent advances in biohydrogenation of unsatured fatty acids within the rumen microbial ecosystem. Journal of Animal Science, v. 86, p. 397-412, 2008. https://doi.org/10.2527/jas.2007$\underline{0588}$

KANEKO J.J.; HARVEY J.W.; BRUSS M.L. Clinical Biochemistry of Domestic Animals. 6th ed. Academic Press, San Diego. 916p, 2008.

KRUSKAL, W. H., WALLIS, W. A. Use of ranks in one-criterion variance analysis. Journal American Statistical Association, v. 47, p. 583-621. 1952. https://doi.org/10.1080/01621459.1952.10483441

LENKEIT, W.; BECKER, M. Inspeção e apreciação de forragens. Lisboa: Ministério da Economia de Portugal, 1956. 152 p. (Boletim Pecuário, 2).

LEVENE, H. Robust Tests for the equality of variance. In: OLKIN, I. (Ed.) Contributions to Probability and Statistics, Palo Alto, California: Stanford University Press, p. 278-292, 1960.

LILLIEFORS, H. W. On the Kolmogorov-Smirnov test for normality with mean and variance unknown. Journal of the American Statistical Association. 62(3), 399-402, 1967. https://doi.org/10.1080/01621459.1967.10482916

MACEDO JUNIOR, G. L. Exigências nutricionais de ovelhas gestantes da raça Santa Inês. 2008. 291f. Tese (Doutorado em Zootecnia) - Universidade Federal de Minas Gerais, Belo Horizonte, MG, 2008.

MACEDO JUNIOR, G.L. Influência dos diferentes níveis de FDN dietético no consumo, digestibilidade aparente e comportamento ingestivo de ovelhas Santa Inês. 2004. 127f. Dissertação (Mestrado em Zootecnia) - Universidade Federal de Lavras, Lavras, MG, 2004. 
MACEDO JUNIOR, G. L.; FERREIRA, M. I. C.; BORGES, I.; SILVA, V. B.; COUTO, J. R. L.; CAVALCANTI, L. F. L. Consumo e digestibilidade aparente das frações fibrosas por ovelhas gestantes submetidas ou não à restrição nutricional. Revista Brasileira de Saúde e Produção Animal. v.11, n.1, p 179-192, 2010.

MACEDO JUNIOR, G. L.; PEREZ, J. R. O.; DE PAULA, O. J.; ALMEIDA, T. R. V.; ASSIS, R. M.; FRANÇA, P. M.; SILVA, V.B.; BORGES, I.; BAIÃO, A. A.F. Níveis de fibra em detergente neutro na alimentação de ovelhas Santa Inês gestantes. Arquivo Brasileiro de Medicina Veterinária e Zootecnia, v.61, n.1, p.196-202, 2009. https://doi.org/10.1590/S0102-09352009000100028

MILlEN, D. D.; PACHECO, R. D. L.; ARRIGONI, M. D. A.; GALYEAN, M. L.; VASCONCELOS, J. T. A snapshot of management practices and nutritional recommendations used by feedlot nutritionists in Brazil. Journal of Animal Science, v. 87, n. 10, p. 3427-3439, 2009. https://doi.org/10.2527/jas.2009-1880

NATIONAL RESEARCH COUNCIL - NRC. Nutrient Requeriments of Small Ruminants. 1.ed. Washington, DC, USA: National Academy Press, 362p. 2007.

OLIVEIRA. C. A.; MILLEN. D. D. Survey of the nutritional recommendations and managementpractices adopted by feedlot cattle nutritionists in Brazil. Animal Feed Science and Technology, v. 197, p. 64-75, 2014. https://doi.org/10.1016/j.anifeedsci.2014.08.010

OLIVEIRA, D. M.; LADEIRA, M. M.; CHIZZOTTI, M. L.; MACHADO NETO, O. R.; RAMOS, E. M.; GONÇALVES, T. M.; BASSI, M. S.; LANNA, D. P. D.; RIBEIRO, J. S. Fatty acid profile and qualitative characteristics of meat from zebu steers fed with different oilseeds. Journal of Animal Science. 89:2546-2555, 2011. https://doi.org/10.2527/jas.2010-3553

PALMQUIST, D. L.; MATTOS, W. R. S. Metabolismo de Lipídeos. In: BERCHIELLI, T. T.; PIRES, A. V.; OLIVEIRA, S. G. Nutrição de Ruminantes. Jaboticabal: Funep, 2006. p.287-310. 
PILAR, R. C.; PÉREZ, R. J. O.; SANTOS, C. L. Manejo reprodutivo da ovelha: recomendação para uma parição a cada oito meses. Boletim Agropecuário, Lavras, n. 50 , p. $1-28$, out. 2002.

PINTO, A. C. J.; MILLEN, D. D. Situação atual da engorda de bovinos em confinamento e modelos nutricionais em uso. In: Sebastião de Campos Valadares Filho et al. (Org.). Simpósio de Produção de Gado de Corte (X Simcorte). 1ed.Viçosa/MG: UFV, v. 1, p. 103-120, 2016.

QUEIROZ, A.C.; NEVES, J.S.; MIRANDA, L.F.; PEREIRA, J.C.; PEREIRA, E.S.; DUTRA, A.R. Efeito do nível de fibra e da fonte de proteína sobre o comportamento alimentar de novilhas mestiças Holandês-Zebu. Arquivo Brasileiro de Medicina Veterinária e Zootecnia, v.53, n.1, p.84-88, 2001. https://doi.org/10.1590/S0102$\underline{09352001000100013}$

RIBEIRO, A. C.; SANTANA, A. F.; LIMA, M. C.; SOUZA, R. S.; NASCIMENTO, J. P. V. Peso ao nascer de ovinos da raça Santa Inês no município de Irará - Bahia. PUBVET, Londrina, v. 2, n. 32, p. 1982-1263, 2008.

RUSSEL, A. J. F.; DONEY, J. M.; GUNN, R. G. Subjective assessment of body fat in live sheep. The Journal of Agricultural Science, v. 72, p.451-454. 1969. https://doi.org/10.1017/S0021859600024874

SÁ, J.L.; OTTO DE SÁ, C. Condição corporal de ovinos. 2001. Disponível em: <http://www.crisa.vet.br/exten 2001/score.htm> Acesso em: 08/02/2017.

SAMPAIO, I. B. M. Estatística aplicada a experimentação animal. $2^{\mathrm{a}}$ ed. Belo Horizonte, FEPMVZ. 265p, 2002.

SAS INSTITUTE. SAS user's guide: statistics, version 9.4. Cary: SAS Institute, 2012. 
SCHAFHÄUSER Jr., J.; MANCIO, A. B.; FONTES, C. A. A.; TORRES, A. A.; PAULINO, M. F.; CECON, P. R. Desempenho reprodutivo de novilhas com diferentes graus de musculosidade. Agronomia. Porto Alegre, v. 10, 2004.

SHAPIRO, S. S. \& Wilk, M. B. An analysis of variance teste for normality. Biometrika 52(4), 591-611, 1965. https://doi.org/10.1093/biomet/52.3-4.591

SILVA, E. N.; DUARTE, J. B.; REIS, A. J. Seleção da matriz de variânciacovariância residual na análise de ensaios varietais com medidas repetidas em cana-de-açúcar. Ciência Rural, 45(4), 993-999, 2015. https://doi.org/10.1590/0103$\underline{8478 \mathrm{cr} 20141531}$

SILVA, D. A. V.; HOMEM JÚNIOR, A. C.; EZEQUIEL, J. M. Sexo e fontes de lipídeos sobre os parâmetros sanguíneos de ovinos confinados. Revista Brasileira de Medicina Veterinária. 36(2), 153-158, 2014.

VAN SOEST, J.P. Nutritional Ecology of the Ruminant. Constock Publishing Associates, London, 2 ed., 476 p. 1994. https://doi.org/10.7591/9781501732355

VARANIS, L.F.M. Prospecção de metabólitos sanguíneos referenciais para ovinos em distintas categorias. 2018. 90f. Dissertação (Mestrado em Ciências Veterinárias) - Universidade Federal de Uberlândia, Uberlândia, MG.

VAZQUEZ-AÑON M.; BERTICS S.; LUCK M.; GRUMMER R.R.; PINHEIRO J. Peripartum liver triglyceride and plasma metabolites in dairy cows. Journal of Dairy Science. 77(6), 1521-1528, 1994. https://doi.org/10.3168/jds.S0022$\underline{0302(94) 77092-2}$ 